\title{
Endogenous intoxication indicators in advanced peritonitis and their correction
}

\author{
E. T. Mammadova \\ Azerbaijan Medical University, Baku

\section{Показатели эндогенной интоксикации при распространенном перитоните и их коррекция} \\ Е. Т. Мамедова \\ Азербайджанский медицинский университет, г. Баку
}

\begin{abstract}
Objective. To study the lipid peroxidation processes and endogenous intoxication indicators in patients with widespread peritonitis before surgery and during the treatment.

Materials and methods. The study included 97 patients (43 men and 54 women) aged from 17 to 69 years with purulent peritonitis. According to treatment scheme, patients were divided into two groups. Patients in group 1 received standard treatment, and in patients in group 2 standard treatment was supplemented by immunoreactions. The concentration of diene conjugates and malonic dialdehyde, reduced glutathione, catalase activity and the concentration of medium molecular weight peptides were determined in the blood of patients and almost healthy people.

Results. The concentration of diene conjugates, malonic dialdehyde and medium molecular weight peptides in the blood of patients with advanced peritonitis increased significantly depending on the clinical stage of the disease, while the activity of the enzyme catalase and the concentration of reduced glutathione were decreased.

Conclusions. Immunoreactions in combination with standard treatment leads to normalization of lipid peroxidation and reduction of endogenous intoxication on the 5 th and 10 th days of treatment.

Keywords: widespread peritonitis; lipid peroxidation; medium molecular peptides.

Реферат

Цель. Изучение процессов перекисного окисления липидов и показателей эндогенной интоксикации у больных с распространенным перитонитом до операции и в динамике лечения.

Материалы и методы. В исследование включены 97 пациентов (43 мужчины и 54 женщины) в возрасте 17 - 69 лет с гнойным перитонитом. Согласно схеме лечения пациенты распределены на две группы. Пациентам 1-й группы проводилось стандартное лечение, а у пациентов 2-й группы стандартное лечение дополнялось иммунокоррекцией. В крови пациентов и практически здоровых людей определяли концентрацию диеновых конъюгатов и малонового диальдегида, восстановленного глутатиона, активность каталазы и концентрацию среднемолекулярных пептидов.

Результаты. Концентрация диеновых коньюгатов, малонового диальдегида и среднемолекулярных пептидов в крови пациентов с распространенным перитонитом значительно увеличивалась в зависимости от клинической стадии заболевания, в то время как активность фермента каталазы и концентрация восстановленного глутатиона снижались. Выводы. Иммунокоррекция в сочетании со стандартным лечением приводит к нормализации показателей перекисного окисления липидов и снижению эндогенной интоксикации на 5-й и 10-й дни лечения.

ключевые слова: распространенный перитонит; перекисное окисление липидов; среднемолекулярные пептиды.
\end{abstract}

Despite of the achievements in abdominal surgery, the treatment of diffuse peritonitis appears as a complex and important medical problem. Application of some antibiotics and antiseptics do not reduce the number of purulent complications, reaching up to $10-23 \%$ with a mortality rate $20-35 \%$, and the incidence of septic shock up to $60 \%[1,2]$. The results of current studies show that in diffuse peritonitis, the systemic inflammatory response syndrome and the progression of severe endotoxicosis constitutes the main factors of increased mortality $[2,3]$. Bacteremia, endotoxemia, and the accumulation of metabolic products, that contribute to the systemic inflammatory response, are considered as a main substrate of the disorder $[4,5]$.
Endogenous intoxication in purulent peritonitis is a complex and multicomponent process, which involves bacterial toxins, proteolytic enzymes, biologically active substances, MMWP, LP products [5-7]. While the development of endogenous intoxication with peritonitis, a cascade activation of the LP processes occurs, leading to multiple organ failure and unsatisfactory outcome $[6,8]$. Thus, decay products, formed as a result of intensification of the LP processes and active oxygen radicals have a detrimental effect on proteins, nucleic acids and other cell structures, disrupt metabolism, acting as an endopathogenic factor. An imbalance between LP products and the antioxidant system (AOS) underlies the disruption of the stability of cellular membranes 
and the development of endotoxicosis [9-11]. Despite of numerous studies, concerning studying of role of the oxidative and antioxidant systems indicators in the pathogenesis of diffuse peritonitis, their relationship with endogenous intoxication and prognostic significance are not fully understood. Timely diagnosis of the LP processes, identification of their role in development of endotoxemia are necessary for a timely drug prescription and adequate therapy, as well as performing reoperations.

The aim of the study: was to study the LP processes and parameters of endogenous intoxication in patients with diffuse peritonitis before and during its treatment.

\section{Materials and methods}

In the study 97 patients ( 54 women and 43 men) aged $17-69$ yrs old with diffuse peritonitis of different etiology were included. All of them were examined and treated at the Department of Surgical Diseases № 3 of Medical University of Azerbaijan during 2012 - 2015 yrs. Purulent peritonitis was caused by destructive appendicitis in $44 \mathrm{pa}-$ tients, perforated ulcer (of the stomach -9 and duodenum - 14) - in 23 patients, destructive cholecystitis (11), gynecological pathology (15), acute intestinal obstruction (4). Reactive stage of peritonitis was diagnosed in 16 patients; a toxic one -in 72 and terminal - in 9. The diagnosis was confirmed by the patient's history data, results of clinical, radiological and laboratory examinations.

All 97 patients studied were divided into two groups. In the 1st group 52 patients were included, who received basic therapy, while into the 2 nd group -45 , who received antioxidant therapy in addition to basic treatment.

The blood parameters were studied on the 1st, 5 th and 10th days of illness in each group.

The LP concentration and AOS of patients was determined in peripheral blood: concentration of the diene conjugates (DC) in accordance to method of V. D. Gavrilov et al [12], the concentration of MDA - in accordance to method of L. I. Andreev et al [13], MMWP concentration - in accordance to procedure of V. V. Nikolaichuk et al [14], concentration of GSH - in accordance to method of Anderson M.E. et al. [17], and the catalase activity - in accordance to method of M.A.Koroluk et al.[18].

Statistical analysis was performed using "Exell-97" ("Microsoft office").

\section{Results}

Here in it was shown, that concentration of biochemical markers of endogenous intoxication and the LP process - DC, MDA and MMWP - are increasing, while the catalase activity, while the level of the reduced glutathione (GSH) are decreasing with the illness severity enhancement. In accordance with these shifts, the blood concentration levels of DC and MDA were statistically elevated in patients of the first group compared to control group - by $53.7 \%\left(\mathrm{p}_{\mathrm{U}}=0.001\right) \%$ and by $56.3 \%\left(p_{U}=0.008\right)$, respectively, and by $49.3 \%\left(p_{U}=0.013\right)$ and by $67.0 \%\left(p_{U}=0.005\right)$ - in the second group, respectively.
DC and MDA were significantly higher - in 2.0 times ( $\mathrm{p}$ $\left.{ }_{\mathrm{U}}<0.001\right)$ and 2.5 times $\left(\mathrm{p}_{\mathrm{U}}<0.001\right)$, respectively, in the $1 \mathrm{st}$ group of patients and in 2.2 times $\left(\mathrm{p}_{\mathrm{U}}<0.001\right)$ and 2.4 times $\left(\mathrm{p}_{\mathrm{U}}<0.001\right)$, respectively, in patients of the 2nd group with toxic stage of peritonitis, compared to control group.

In the 1st group of patients with terminal stage of peritonitis the DC and MDA concentrations were significantly increased - in 2.8 times $\left(\mathrm{p}_{\mathrm{U}}=0.002\right)$ and in 3.8 times $\left(\mathrm{p}_{\mathrm{U}}=\right.$ $0.002)$, respectively, compared to control group, in patients of the 2nd group - in 3.8 times $\left(\mathrm{p}_{\mathrm{U}}=0.001\right)$ and in 4.2 times $\left(\mathrm{p}_{\mathrm{U}}=0.001\right)$, respectively.

The catalase activity and concentration of the reduced GSH were studied as an important indicators of AOS. According to the study results, the catalase activity was significantly lower in patients with reactive phase of the disease - in the 1st group by $30.1 \%\left(\mathrm{p}_{\mathrm{U}}=0.002\right)$ and by $29.6\left(\mathrm{p}_{\mathrm{U}}=\right.$ 0.005 ) in the 2 nd group - comparing to control group. In this stage of peritonitis the GSH concentration in the 1st group was lower by $26.4 \%\left(\mathrm{p}_{\mathrm{U}}=0.001\right)$ and by $21.3 \%\left(\mathrm{p}_{\mathrm{U}}=\right.$ 0.071 ) in the 2 nd group, respectively, in comparison to the control group.

Activity of the blood catalase in patients with toxic phase of peritonitis of the 1st group was decreased by $45.4 \%\left(\mathrm{p}_{\mathrm{U}}\right.$ $<0.001)$ and in patients of the 2 nd group - by $43.8 \%\left(\mathrm{p}_{\mathrm{U}}\right.$ $<0.001)$, respectively, compared to control group. The GSH concentration was significantly lower, than in control group in the 1 st and the 2 nd groups - by $46.7 \%\left(\mathrm{p}_{\mathrm{U}}<0.001\right)$ and by $45.0 \%\left(\mathrm{p}_{\mathrm{U}}<0.001\right)$, respectively.

Activity of the blood catalase in patients with terminal stage of peritonitis in the 1st group was significantly decreased - in 2,2 times $\left(\mathrm{p}_{\mathrm{U}}=0.006\right)$, while in 2,2 times $\left(\mathrm{p}_{\mathrm{U}}=\right.$ 0.004 ) - in the 2nd group, compared to control group. In this stage of the disease the GSH concentration was significantly lower, compared to control in the 1st and 2nd groups in 2.2 times $\left(\mathrm{p}_{\mathrm{U}}=0.002\right)$ and 2.4 times $\left(\mathrm{p}_{\mathrm{U}}=0.001\right)$, respectively.

Thus, in the patients with diffuse peritonitis the blood DC and MDA concentrations were significantly increased, while the catalase activity and the reduced GSH concentrations were decreased in accordance to severity of the disease (see figure).

In the patients with reactive stage of peritonitis the blood concentration of MMWP was significantly increased - by $86.4 \%\left(\mathrm{p}_{\mathrm{U}}<0.001\right)$ in the 1 st group and by $76.4 \%\left(\mathrm{p}_{\mathrm{U}}=0.006\right)$ in the 2nd group.

The concentration of MMWP in the blood of patients of the 1 st and 2 nd groups with toxic stage of peritonitis was significantly respectively higher - in 3.3 times $\left(\mathrm{p}_{\mathrm{U}}<0.001\right)$ and 3.1 times $\left(\mathrm{p}_{\mathrm{U}}<0.001\right)$, compared to control.

The blood MMWP concentration in patients with terminal stage of peritonitis of the 1 st and the $2 \mathrm{~d}$ groups was respectively higher - in 4.9 times $\left(\mathrm{p}_{\mathrm{U}}=0.002\right)$ and in 5.3 times $\left(\mathrm{p}_{\mathrm{U}}=0.001\right)$ - compared to control level.

Changes of the endogenous intoxication indicators (DC, MDA, catalase, GSH and MMWP) were observed in the course of surgical treatment on the 1 st, the 5 th and the 10 th days after surgery. 
The studies have shown, that in the 1st group of patients with reactive stage of diffuse peritonitis on the 5 th day after surgery the DC and MDA concentrations have tended to increase and on the 10th day they were decreased, compared to previous day. But at the same time, the DC and MDA concentrations were higher than in the control group - by $40.2 \%\left(p_{U}=0.029\right) \%$ and by $39.2 \%\left(p_{U}=0.036\right)$, respectively, on the 10 day after surgery (Table 1 ).

On the 10th day after the operation in patients with reactive stage of the disease the catalase activity was significantly increased - by $12.4 \%\left(\mathrm{p}_{\mathrm{U}}=0.021\right)$, compared to preoperative values. The catalase activity and the reduced GSH concentration were significantly decreased - by $21.4 \%\left(\mathrm{p}_{\mathrm{U}}=0.002\right)$ and by $21.1 \%\left(p_{U}=0.007\right)$, compared to control group.

As a result of study of patients in the 1st group with diffuse stage of peritonitis, the MMWP concentration have tended to increase on the 1st day after surgery, it did not differ on the 5 th day and it have been decreased on the 10th day after surgery. But its concentration was increased - by $54.5 \%$ $\left(p_{U}=0.002\right)$ on the 10th day after surgery, compared to the control group.

In patients with toxic stage of peritonitis of the 1st group the DC and MDA concentrations were decreased - by $12.8 \%$

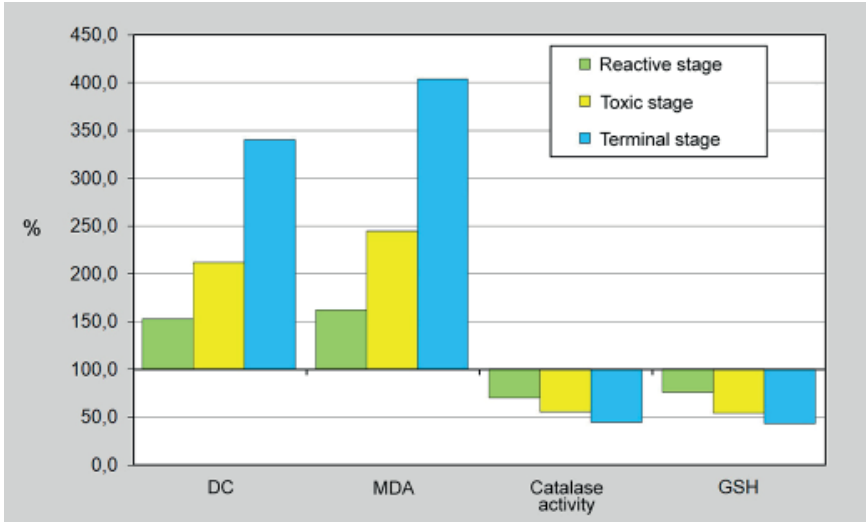

Show Teli processes of lipid peroxidation in the blood of patients with spread of $m$ peritonitis.

$\left(\mathrm{p}_{\mathrm{U}}=0.036\right) \%$ and $16.9\left(\mathrm{p}_{\mathrm{U}}=0.001\right)$, respectively, on the 1 st day after surgery - by $10.4 \%\left(p_{U}=0.016\right)$ and by $10.4 \%$ $\left(\mathrm{p}_{\mathrm{U}}=0.002\right)$ on the 5 th day and by $11.8 \%\left(\mathrm{p}_{\mathrm{U}}=0.020\right)$ and $22.4 \%\left(\mathrm{p}_{\mathrm{U}}<0.001\right)$ on the 10th day, compared to preoperative values. On the 10th day after surgery the DC and MDA concentrations were increased - by $80.6 \%\left(\mathrm{p}_{\mathrm{U}}<0.001\right)$ and 98.4\% ( $\left.\mathrm{p}_{\mathrm{U}}<0.001\right)$, respectively, compared to control group. The catalase activity and the reduced GSH concentration did

Table 1. Effect of the standard treatment for the LPP concentration and parameters of AOS in depends on different stages of diffuse peritonitis different stages of diffuse peritonitis (1st group)

\begin{tabular}{|c|c|c|c|c|c|c|}
\hline \multirow{2}{*}{ Parameters } & \multirow{2}{*}{ Control } & \multirow{2}{*}{ Peritonitis stage } & \multirow{2}{*}{ Before treatment } & \multicolumn{3}{|c|}{ After treatment, day } \\
\hline & & & & $1 \mathrm{st}$ & 5 th & 10 th \\
\hline \multirow{3}{*}{$\mathrm{DC}, \mathrm{D}_{233} / \mathrm{ml}$} & \multirow{3}{*}{$\begin{array}{c}0,443 \pm 0,025 \\
(0,11-0,54)\end{array}$} & Reactive & $\begin{array}{c}0,668 \pm 0,049 * \\
(0,37-0,81)\end{array}$ & $\begin{array}{c}0,831 \pm 0,170^{* \wedge} \\
(0,48-2,15)\end{array}$ & $\begin{array}{c}0,780 \pm 0,136^{*} \\
(0,47-1,84)\end{array}$ & $\begin{array}{c}0,609 \pm 0,084^{*} \\
(0,3-1,17)\end{array}$ \\
\hline & & Toxic & $\begin{array}{c}0,889 \pm 0,028^{*} \\
(0,57-1,18)\end{array}$ & $\begin{array}{c}1,004 \pm 0,042^{* \wedge} \\
(0,53-1,48)\end{array}$ & $\begin{array}{c}0,797 \pm 0,023^{* \wedge} \\
(0,53-1,06)\end{array}$ & $\begin{array}{c}0,785 \pm 0,025^{* \wedge} \\
(0,43-1,15)\end{array}$ \\
\hline & & Terminal & $\begin{array}{c}1,230 \pm 0,321^{*} \\
(0,75-2,14)\end{array}$ & $\begin{array}{c}1,283 \pm 0,261^{*} \\
(0,79-1,68)\end{array}$ & $\begin{array}{c}0,943 \pm 0,132 * \\
(0,68 \pm 1,09)\end{array}$ & $\begin{array}{c}0,863 \pm 0,167^{*} \\
(0,57-1,15)\end{array}$ \\
\hline \multirow{3}{*}{$\begin{array}{l}\mathrm{MDA}, \\
\mathrm{mmol} / \mathrm{ml}\end{array}$} & \multirow{3}{*}{$\begin{array}{c}3,82 \pm 0,33 \\
(1,45-6,05)\end{array}$} & Reactive & $\begin{array}{l}5,98 \pm 0,58^{*} \\
(3,00-8,60)\end{array}$ & $\begin{array}{l}7,91 \pm 0,81^{* \wedge} \\
(4,90-11,90)\end{array}$ & $\begin{array}{c}6,57 \pm 0,70^{*} \\
(4,00-10,60)\end{array}$ & $\begin{array}{l}5,32 \pm 0,51^{*} \\
(2,40-7,00)\end{array}$ \\
\hline & & Toxic & $\begin{array}{l}9,38 \pm 0,20 * \\
(6,40-12,5)\end{array}$ & $\begin{array}{c}10,97 \pm 0,26^{* \wedge} \\
(8,40-14,40)\end{array}$ & $\begin{array}{l}8,23 \pm 0,25^{* \wedge} \\
(5,80-12,50)\end{array}$ & $\begin{array}{l}7,28 \pm 0,18^{* \wedge} \\
(5,50-11,10)\end{array}$ \\
\hline & & Terminal & $\begin{array}{c}14,50 \pm 5,11 * \\
(8,90 \pm 29,8)\end{array}$ & $\begin{array}{c}15,47 \pm 2,40^{*} \\
(10,70-18,40)\end{array}$ & $\begin{array}{l}11,23 \pm 2,14 * \\
(7,20-14,50)\end{array}$ & $\begin{array}{l}10,27 \pm 1,68^{*} \\
(7,30-13,10)\end{array}$ \\
\hline \multirow{3}{*}{$\begin{array}{c}\text { Catalase } \\
\text { activity, } \\
\text { mkat/l }\end{array}$} & \multirow{3}{*}{$\begin{array}{c}15,8 \pm 0,9 \\
(6,4-19,8)\end{array}$} & Reactive & $\begin{array}{l}11,0 \pm 0,4^{*} \\
(8,7-13,6)\end{array}$ & $\begin{array}{l}11,1 \pm 0,6^{*} \\
(8,7-12,9)\end{array}$ & $\begin{array}{c}11,8 \pm 0,4^{*} \\
(10,1-13,3)\end{array}$ & $\begin{array}{c}12,4 \pm 0,3 * \\
(11,4-13,9)\end{array}$ \\
\hline & & Toxic & $\begin{array}{c}8,6 \pm 0,1^{*} \\
(7,4-10,5)\end{array}$ & $\begin{array}{l}9,5 \pm 0,2^{* \wedge} \\
(7,0-11,6)\end{array}$ & $\begin{array}{c}10,9 \pm 0,3^{* \wedge} \\
(8,3-14,1)\end{array}$ & $\begin{array}{c}11,5 \pm 0,2^{* \wedge} \\
(9,9-13,7)\end{array}$ \\
\hline & & Terminal & $\begin{array}{l}7,1 \pm 0,9^{*} \\
(5,4-9,6)\end{array}$ & $\begin{array}{c}8,4 \pm 1,4^{*} \\
(6,9-11,2)\end{array}$ & $\begin{array}{c}9,2 \pm 1,5^{*} \\
(7,6-12,2)\end{array}$ & $\begin{array}{c}9,7 \pm 1,1^{*} \\
(8,5-11,9)\end{array}$ \\
\hline \multirow{3}{*}{$\begin{array}{l}\text { GSH, } \mu \mathrm{mol} / \mathrm{g} \\
\text { hemoglobin }\end{array}$} & \multirow{3}{*}{$\begin{array}{c}1,58 \pm 0,11 \\
(1,11-2,93)\end{array}$} & Reactive & $\begin{array}{l}1,16 \pm 0,03^{*} \\
(1,09-1,30)\end{array}$ & $\begin{array}{c}1,05 \pm 0,04^{* \wedge} \\
(0,89-1,22)\end{array}$ & $\begin{array}{l}1,13 \pm 0,03^{*} \\
(1,02-1,21)\end{array}$ & $\begin{array}{l}1,24 \pm 0,04 * \\
(1,10-1,44)\end{array}$ \\
\hline & & Toxic & $\begin{array}{l}0,84 \pm 0,02^{*} \\
(0,55-1,20)\end{array}$ & $\begin{array}{c}0,91 \pm 0,03^{* \wedge} \\
(0,62-1,35)\end{array}$ & $\begin{array}{c}0,98 \pm 0,04^{* \wedge} \\
(0,54-1,41)\end{array}$ & $\begin{array}{c}1,13 \pm 0,04^{* \wedge} \\
(0,53-1,57)\end{array}$ \\
\hline & & Terminal & $\begin{array}{l}0,71 \pm 0,13^{*} \\
(0,42-0,98)\end{array}$ & $\begin{array}{l}0,80 \pm 0,23^{*} \\
(0,54-1,25)\end{array}$ & $\begin{array}{l}0,92 \pm 0,25^{*} \\
(0,65-1,42)\end{array}$ & $\begin{array}{l}0,94 \pm 0,15^{*} \\
(0,76-1,24)\end{array}$ \\
\hline \multirow{3}{*}{ MMWP, g/l } & \multirow{3}{*}{$\begin{array}{c}0,539 \pm 0,029 \\
(0,32-0,69)\end{array}$} & Reactive & $\begin{array}{c}1,006 \pm 0,099^{*} \\
(0,56-1,48)\end{array}$ & $\begin{array}{c}1,128 \pm 0,102 * \\
(0,65-1,68)\end{array}$ & $\begin{array}{c}0,978 \pm 0,092^{*} \\
(0,40-1,32)\end{array}$ & $\begin{array}{c}0,833 \pm 0,079^{*} \\
(0,40-1,20)\end{array}$ \\
\hline & & Toxic & $\begin{array}{c}1,759 \pm 0,054^{*} \\
(1,02-2,31)\end{array}$ & $\begin{array}{c}1,546 \pm 0,060^{* \wedge} \\
(0,93-2,25)\end{array}$ & $\begin{array}{c}1,361 \pm 0,045^{* \wedge} \\
(0,63-1,78)\end{array}$ & $\begin{array}{c}1,115 \pm 0,038^{* \wedge} \\
(0,59-1,47)\end{array}$ \\
\hline & & Terminal & $\begin{array}{c}2,650 \pm 0,866^{*} \\
(1,10-4,90)\end{array}$ & $\begin{array}{c}2,367 \pm 0,884^{*} \\
(1,20-4,10)\end{array}$ & $\begin{array}{c}1,867 \pm 0,524^{*} \\
(1,20-2,90)\end{array}$ & $\begin{array}{c}1,533 \pm 0,078^{*} \\
(1,10-2,20)\end{array}$ \\
\hline Note. & 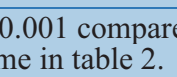 & the indic & the control grol & $-\mathrm{p}<0.001-\mathrm{com}$ & $d$ with the indica & before treatment \\
\hline
\end{tabular}


Table 2. Effect of combined treatment for the LPP concentration and parameters of AOS in depends on different stages of diffuse peritonitis (2nd group)

\begin{tabular}{|c|c|c|c|c|c|c|}
\hline \multirow{2}{*}{ Parameters } & \multirow{2}{*}{ Control } & \multirow{2}{*}{ Peritonitis stage } & \multirow{2}{*}{ Before treatment } & \multicolumn{3}{|c|}{ After treatment, day } \\
\hline & & & & $1 \mathrm{st}$ & 5-й & 10-й \\
\hline \multirow{3}{*}{$\mathrm{DC}, \mathrm{D}_{233} / \mathrm{ml}$} & \multirow{3}{*}{$\begin{array}{c}0,443 \pm 0,025 \\
(0,11-0,54)\end{array}$} & Reactive & $\begin{array}{c}0,649 \pm 0,085^{*} \\
(0,27-0,93)\end{array}$ & $\begin{array}{c}0,921 \pm 0,122 * \\
(0,49-1,37)\end{array}$ & $\begin{array}{c}0,623 \pm 0,096 \\
(0,34-0,99)\end{array}$ & $\begin{array}{c}0,487 \pm 0,078 \\
(0,28-0,88)\end{array}$ \\
\hline & & Toxic & $\begin{array}{c}0,940 \pm 0,023 * \\
(0,58-1,20)\end{array}$ & $\begin{array}{c}1,021 \pm 0,020 * \\
(0,78-1,30)\end{array}$ & $\begin{array}{c}0,672 \pm 0,016^{* \wedge} \\
(0,47-0,92)\end{array}$ & $\begin{array}{c}0,566 \pm 0,013 * \wedge \\
(0,34-0,73)\end{array}$ \\
\hline & & Terminal & $\begin{array}{c}1,668 \pm 0,255^{*} \\
(0,86-2,37)\end{array}$ & $\begin{array}{c}1,254 \pm 0,152^{* \wedge} \\
(0,85-1,69)\end{array}$ & $\begin{array}{c}0,870 \pm 0,085^{*} \\
(0,75-1,12)\end{array}$ & $\begin{array}{c}0,648 \pm 0,109 \\
(0,42-0,94)\end{array}$ \\
\hline \multirow{3}{*}{$\begin{array}{l}\text { MDA, } \\
\mathrm{mmol} / \mathrm{ml}\end{array}$} & \multirow{3}{*}{$\begin{array}{c}3,82 \pm 0,33 \\
(1,45-6,05)\end{array}$} & Reactive & $\begin{array}{l}6,39 \pm 0,78^{*} \\
(2,90-9,80) \\
\end{array}$ & $\begin{array}{c}8,13 \pm 0,93^{*} \\
(4,90-12,70)\end{array}$ & $\begin{array}{c}5,31 \pm 0,71 \\
(3,70-9,40) \\
\end{array}$ & $\begin{array}{c}4,54 \pm 0,50 \\
(2,00-6,30)\end{array}$ \\
\hline & & Toxic & $\begin{array}{l}9,28 \pm 0,19^{*} \\
(6,60-12,1)\end{array}$ & $\begin{array}{c}10,86 \pm 0,28^{* \wedge} \\
(7,40-15,70)\end{array}$ & $\begin{array}{c}7,45 \pm 0,23^{* \wedge} \\
(4,20-9,60)\end{array}$ & $\begin{array}{c}5,93 \pm 0,15^{* \wedge} \\
(3,60-7,60)\end{array}$ \\
\hline & & Terminal & $\begin{array}{c}16,12 \pm 4,25^{*} \\
(9,20-32,6)\end{array}$ & $\begin{array}{l}15,14 \pm 1,61^{*} \\
(8,90-17,80)\end{array}$ & $\begin{array}{l}9,15 \pm 1,27^{*} \\
(6,80-12,4)\end{array}$ & $\begin{array}{c}6,93 \pm 1,42 \\
(4,60-10,90)\end{array}$ \\
\hline \multirow{3}{*}{$\begin{array}{c}\text { Catalase } \\
\text { activity, } \\
\text { mkat/1 }\end{array}$} & \multirow{3}{*}{$\begin{array}{c}15,8 \pm 0,9 \\
(6,4-19,8)\end{array}$} & Reactive & $\begin{array}{l}11,1 \pm 0,5^{*} \\
(9,1-12,7)\end{array}$ & $\begin{array}{l}10,2 \pm 0,4^{*} \\
(8,7-11,8)\end{array}$ & $\begin{array}{c}12,6 \pm 0,6^{*} \\
(10,5-14,5)\end{array}$ & $\begin{array}{c}14,7 \pm 0,6^{\wedge} \\
(11,8-16,8)\end{array}$ \\
\hline & & Toxic & $\begin{array}{c}8,9 \pm 0,1^{*} \\
(6,7-10,8)\end{array}$ & $\begin{array}{c}9,1 \pm 0,1^{*} \\
(7,2-11,0)\end{array}$ & $\begin{array}{c}11,7 \pm 0,2 * \wedge \\
(9,7-13,7)\end{array}$ & $\begin{array}{l}12,9 \pm 0,2^{* \wedge} \\
(10,9-15,7)\end{array}$ \\
\hline & & Terminal & $\begin{array}{l}7,1 \pm 0,6^{*} \\
(5,1-8,9)\end{array}$ & $\begin{array}{l}7,4 \pm 0,6^{*} \\
(6,7-9,8)\end{array}$ & $\begin{array}{l}10,6 \pm 1,2 * \\
(8,5-13,5)\end{array}$ & $\begin{array}{l}11,6 \pm 1,0 * \\
(9,8-14,3)\end{array}$ \\
\hline \multirow{3}{*}{$\begin{array}{c}\mathrm{GSH}, \\
\mu \mathrm{mol} / \mathrm{g} \\
\text { hemoglobin }\end{array}$} & \multirow{3}{*}{$\begin{array}{c}1,58 \pm 0,11 \\
(1,11-2,93)\end{array}$} & Reactive & $\begin{array}{l}1,24 \pm 0,13 * \\
(0,94-1,80)\end{array}$ & $\begin{array}{l}0,98 \pm 0,07 * \\
(0,81-1,23)\end{array}$ & $\begin{array}{l}1,27 \pm 0,10^{*} \\
(1,03-1,73)\end{array}$ & $\begin{array}{c}1,49 \pm 0,20 \\
(1,07-2,48)\end{array}$ \\
\hline & & Toxic & $\begin{array}{l}0,87 \pm 0,01^{*} \\
(0,67-1,10)\end{array}$ & $\begin{array}{l}0,87 \pm 0,01^{*} \\
(0,60-1,00)\end{array}$ & $\begin{array}{c}1,18 \pm 0,02^{* \wedge} \\
(0,90-1,50)\end{array}$ & $\begin{array}{c}1,32 \pm 0,02^{* \wedge} \\
(0,92-1,63)\end{array}$ \\
\hline & & Terminal & $\begin{array}{l}0,64 \pm 0,08^{*} \\
(0,41-0,87)\end{array}$ & $\begin{array}{l}0,78 \pm 0,12 * \\
(0,54-1,23)\end{array}$ & $\begin{array}{l}1,02 \pm 0,17 * \\
(0,77-1,53)\end{array}$ & $\begin{array}{c}1,19 \pm 0,22 \\
(0,82-1,76)\end{array}$ \\
\hline \multirow{3}{*}{ MMWP, g/l } & \multirow{3}{*}{$\begin{array}{c}0,539 \pm 0,029 \\
(0,32-0,69)\end{array}$} & Reactive & $\begin{array}{c}0,951 \pm 0,147^{*} \\
(0,47-1,58)\end{array}$ & $\begin{array}{c}1,253 \pm 0,163^{*} \\
(0,68-1,96)\end{array}$ & $\begin{array}{c}0,737 \pm 0,100 * \\
(0,38-1,15)\end{array}$ & $\begin{array}{c}0,636 \pm 0,078 \\
(0,37-0,92)\end{array}$ \\
\hline & & Toxic & $\begin{array}{c}1,671 \pm 0,040 * \\
(1,04-2,24)\end{array}$ & $\begin{array}{c}1,623 \pm 0,037^{*} \\
(1,28-2,23)\end{array}$ & $\begin{array}{c}1,155 \pm 0,030^{* \wedge} \\
(0,79-1,60)\end{array}$ & $\begin{array}{c}0,723 \pm 0,019^{* \wedge} \\
(0,50-1,00)\end{array}$ \\
\hline & & Terminal & $\begin{array}{c}2,838 \pm 0,627^{*} \\
(1,65-5,12)\end{array}$ & $\begin{array}{c}2,43 \pm 0,355^{*} \\
(1,24-3,25)\end{array}$ & $\begin{array}{c}1,295 \pm 0,294^{*} \\
(0,90-2,16)\end{array}$ & $\begin{array}{c}0,938 \pm 0,679^{*} \\
(0,77-1,14)\end{array}$ \\
\hline
\end{tabular}

not change significantly on the 1st day after surgery, compared to preoperative values. On the 5 th day after surgery they were increased significantly - by $26.2 \%\left(\mathrm{p}_{U}<0.001\right) \%$ and by $17.2\left(\mathrm{p}_{\mathrm{U}}=0.002\right)$, while on the 10 th day after surgery - by $3 \%\left(\mathrm{p}_{\mathrm{U}}<0.001\right)$ and $35.0 \%\left(\mathrm{p}_{\mathrm{U}}<0.001\right)$, respectively. According to the data, obtained from statistical analysis, the catalase activity and the reduced GSH concentration in the 1st group have remained lower - on the 10th day after the operation, compared to control group.

The significantly decreased MMWP concentration was observed in patients with toxic stage of diffuse peritonitis on the 1 st day after surgery - by $12.1 \%\left(\mathrm{p}_{\mathrm{U}}=0.020\right)$, on the 5 th day - by $22.6 \%\left(\mathrm{p}_{\mathrm{U}}<0.001\right)$, on the 10 th day - by $366 \%$ $\left(\mathrm{p}_{\mathrm{U}}<0.001\right)$. The MMWP concentration have remained below a control level in 2.9 times $\left(\mathrm{p}_{\mathrm{U}}<0.001\right)$ on the 1st day, in 2.5 times $\left(\mathrm{p}_{\mathrm{U}}<0.001\right)-$ on the 5 th day and in 2.1 times ( $\left.\mathrm{p}_{\mathrm{U}}<0.001\right)-$ on the 10th day after surgery.

The DC and MDA concentrations in patients of the 1st group with terminal stage of peritonitis were changed a little, and on the 10th day after operation were decreased by $29.8 \%\left(p_{U}=0.593\right)$ and by $29.2 \%\left(p_{U}=0.593\right)$, respectively, against preoperative values. According to the results of statistical analysis, on the 10th day after the operation, the concentrations of DC and MDA have remained in 2.0 times
$\left(\mathrm{p}_{\mathrm{U}}=0.007\right)$ and in 2.7 times $\left(\mathrm{p}_{\mathrm{U}}=0.007\right)$ elevated, compared to control group.

The catalase activity and the reduced GSH concentrations have tended to increase accordingly - by $29.6 \%\left(\mathrm{p}_{\mathrm{U}}=\right.$ $0.109) \%$ and by $30.0\left(\mathrm{p}_{\mathrm{U}}=0.109\right)$ on the 5 th day after surgery, by $31,9 \%\left(\mathrm{p}_{U}=0.109\right)$ and by $38.1 \%\left(\mathrm{p}_{U}=0.109\right)$ on the 10th day, compared to preoperative values. According to the results of statistical analysis, on the 10th day after surgery, the reduced GSH concentration have remained significantly lower, than in the control group.

In patients of the 1st group with terminal stage of diffuse peritonitis the MMWP concentration was at the control level. On the 1st day after surgery it was not significantly increased - by $29.6 \%\left(p_{U}=0.655\right)$ on the 5 th day, and on the 10 th day - by $42.1 \%\left(p_{U}=0.180\right)$ versus a control group. On the 10th day after surgery the MMWP concentration was elevated in 2.8 times $\left(\mathrm{p}_{\mathrm{U}}=0.007\right)$ against the control level.

Concentration of the LP products and the MMWP was changed against the control values on the 10th day after surgery in group of patients who received the standard treatment. However, their levels were differed significantly, compared to the control group, despite the LP and AOS values had positive changes in patients with reactive and toxic stages of peritonitis. In the patients with terminal stage of peri- 
tonitis the changes of these markers were not significant.

In the 2nd group, where, in addition to the standard treatment, immunoprotectors were used, the values of endogenous intoxication have changed more significantly. Despite the increase of the DC and MDA concentratios in reactive phase on the 1 st day after the operation, after 10 days they, on the contrary, have decreased in comparison with the preoperative values and with the values in the 1st group (Table 2).

The catalase activity and the reduced GSH concentration were increased on the 10th day after surgery and were not significantly different from those in the control group, but were by $18.8 \%\left(p_{U}=0.013\right)$ and by $20.0 \%\left(p_{U}=0.672\right)$ higher than in the 1st group.

In patients with reactive stage of peritonitis, the MMWP concentration was decreased by $22.5 \%\left(p_{U}=0.499\right)$ on the 5 th day and by $33.2 \%\left(\mathrm{p}_{\mathrm{U}}=0.075\right)$ on the 10 th day after surgery. According to statistical data obtained, these patients had the MMWP concentration by $23.7 \%\left(\mathrm{p}_{\mathrm{U}}=0.072\right)$ lower than in the 1 st group on the 10 th day.

In patients with toxic stage of peritonitis the DC and MDA concentrations were studied since 5 th to 10 th day after surgery, comparing to preoperative level. This group of patients had lower concentration of this markers on the 10th day, compared to the 1 st group, but they remained higher than a control level.

The catalase activity and the reduced GSH concentration did not differ significantly between the study groups on the 1 st and the 5 th days after surgery, but their levels were significantly increased - by $12.6 \%\left(\mathrm{p}_{\mathrm{U}}=0.015\right)$ and by $16,8 \%\left(\mathrm{p}_{\mathrm{U}}<0.001\right)$ - on the 10 th day in the 2 nd group, compared to the 1 st.

The patients with toxic stage of peritonitis of the 2 nd group had statistically significantly decreased MMWP concentration - by $30.9 \%\left(\mathrm{p}_{\mathrm{U}}<0.001\right)$ on the 5 th day after surgery and in 2.3 times $\left(\mathrm{p}_{\mathrm{U}}<0.001\right)$ on the 10 th day, but this marker remained higher compared to the control group.

In the patients with terminal stage of diffuse peritonitis the DC and MDA concentrations have restored to the control level to the 10th day after surgery, compared to preoperative level in the 2 nd group. At the same time, the catalase activity and the reduced GSH concentration have tended to be increased - by 49.4\% ( $\left.\mathrm{p}_{\mathrm{U}}=0.068\right) \%$ and by $10.2(\mathrm{p}$ $\mathrm{U}=0.289)$, respectively, and on the 10 th day they were by $64.7 \%\left(\mathrm{p}_{\mathrm{U}}=0.068\right)$ and $85.2 \%\left(\mathrm{p}_{\mathrm{U}}=0.068\right)$ higher, than in the 1 st group. The MMWP concentration was decreased at the 5 th day after surgery - in 2,2 times $\left(\mathrm{p}_{\mathrm{U}}=0.068\right)$, and at 10 th day in 3.0 times $\left(\mathrm{p}_{\mathrm{U}}=0.068\right)$, respectively, and their levels were higher on the 10th day after the surgery, compared to control group.

\section{Discussion}

Based on the results, obtained in patients with diffuse peritonitis, especially in its toxic and terminal stages, the concentration of MDA increases more significantly than concentration of the LP products - DC. It has been estab- lished, that a big amount of cytosolic proteins, entering the blood plasma from destroyed cells, have an prooxidant effect and cause an increase in MDA - the end LP product [5, 8]. A further increasing in the blood DC and MDA concentrations in patients with the toxic and terminal stages of peritonitis indicates a high level of endogenous intoxication, while the increase in the number of LP reaction is explained by weakening of AOS [6, 15].

In diffuse peritonitis a weakening of AOS leads to disruption in the detoxiication system and to oxidative stress. The LP activation as a result of the oxidative stress activation during diffuse peritonitis increases the need for antioxidants and causes a rapid diminution in the AOS potential. This leads to enhancement of number of free radicals formatted and exacerbation of endogenous intoxication. As a result of the diminution of the AOS functioning, the adaptive mechanisms of the organism serve as a background for the development of multiple organ failure [6, 8, 10, 11, 15].

In peritonitis the AOS enzymes activity is sharply decreasing, reflecting the disease severity enhancement . A decreased concentration of reduced GSH in the blood and decreased catalase activity leads to activation of the free radicals formation and accelerates the LP reactions. Generally, glutathione is more abundant in red blood cells, liver, and adrenal glands. It neutralizes sulfhydryl and disulfide groups of proteins, forming complex compounds with toxic metals [6, 16].

MMWP play an important role in the development of the endogenous intoxication syndrome and is considered to be one of its main indicators. MMWP cause hemolysis of erythrocytes, slow down of the erythropoiesis rate, reduction of the leukocytes phagocytic activity, weakening of the cellmediated immunity, and participate in the development of renal and hepatic failure. They play important role in development of peritoneal infection, resulting in protein peroxidation, leading to their degradation and the toxic fragments formation $[7,16]$.

\section{Conclusions}

The standard treatment of diffuse peritonitis can reduce the endogenous intoxication partially. However, immunocorrecting therapy in combination with standard treatment reduces the intensity of inflammatory process and decreases the free radicals formation due to inhibition of synthesis of inflammatory mediators. Combined treatment causes reduction of the blood levels of DC, MDA and MMWP concentration on the 5 th and 10th days of treatment, comparing with the baseline levels, but the catalase activity and the reduced GSH concentration returns to control values. The results of the study may owe practical importance for the treatment of endogenous intoxication in patients with diffuse peritonitis and can be introduced into development of new therapeutic approaches for prevention of septic shock.

Financing. There were no external sources of funding and support. No fees or other compensation were paid. 
Conflict of interest. The author has stated no conflict of interest with respect to this manuscript.

\section{References}

1. Styazhkina SN, Ovechkina IA, Shakirova LC, Khabibullina GF. Peritonitis in modern abdominal surgery. International scientific review. 2017;(4):98-102. Russian.

2. Hall JC, Heel KA, Papadimitriou JM, Platell C. The pathobiology of peritonitis. Gastroenterology. 1998 Jan;114(1):185-96. doi: 10.1016/s0016-5085(98)70646-8. PMID: 9428232.

3. Hasanov MD. Algorithm for assessing the severity of endotosycosis in peritonitis. Bulletin of the Russian Military Medical Academy. 2014;(4):75-8. Russian.

4. Gadzhiev NJ. Immune status, cytokine profile and endogenous intoxication in patients with diffuse peritonitis. Surgery of Ukraine. 2012;(4):67-75. Russian.

5. Vlasov AP, Timoshkin SP, Abramova SV, Vlasov PA, Shibitov VA, Polozova EI. Indicators of endogenous intoxication - criteria of enteral insufficiency in acute peritonitis. Fundamental Research. 2014;(10-60:1066-70. Russian.

6. Dalbaşı E, Gedik E, Tüzün A, Obay BD. Correlation of Malondialdehyde and Antioxidant Enzyme Levels with Peritonitis Severity in Patients with Generalized Peritonitis. Dicle Med J. 2020;47(2):293303. DOI: $10.5798 /$ dicletip.

7. Matveyev SB, Fedorova NV, Godkov MA. Evaluation of endogenous intoxication from average molecular weight peptides in emergencies. Klinicheskaya Laboratornaya Diagnostika. 2009 May;(5):168. Russian.

8. Vlasov AP, Abramova SV, Vlasov PA, Timoshkin SP, Leshchankina NY, Kochetkova TA, et al. Evaluation of enteric insufficiency in terms of lipid peroxidation. Modern problems of science and education. 2014;(6):1101. Russian.
9. Blinkov YU, Sukovatykh BS, Stroyev YUS, Konoplya AI. Characteristics of immune and oxidative disorders in patients with widespread fibrinous-purulent peritonitis. Man and His Health (Kursk). 2010;(1):64-70. Russian.

10. Savytskyi IV, Znamerovsky SG, Dzygal OF. The role of lipid peroxidation in the pathogenesis of experimental peritonitis. Journal of Education, Health and Sport. 2020;10(7):389-95. doi: 10.12775/ JEHS.2020.10.07.041.

11. Ermola YuA. Changes in indicators of lipid peroxidation and antioxidant system in the development of experimental peritonitis. $\mathrm{Pa}$ thology. 2012;(2):92-4. Russian.

12. Gavrilov VB, Gavrilova AR, Khmara NF. Measurement of diene conjugates in blood plasma using the UV absorption of heptane and isopropanol extracts. Lab Delo. 1988;(2):60-4. Russian. PMID: 2452294.

13. Andreeva LI, Kozhemiakin LA, Kishkun AA. Modification of the method of determining lipid peroxidation in a test using thiobarbituric acid. Lab Delo. 1988;(11):41-3. Russian. PMID: 2463416.

14. Nikolaychik VV, Moin VM, KirkovskiyVV, Mazur LI, Lobacheva GA, Bychko GN, et al. A method of determining middle molecules. Lab Delo. 1991;(10):13-8. Russian. PMID: 1722520.

15. Kumar Y, Singh G, Davidson BR. Free radical and antioxidant levels in patients with secondary peritonitis and their prognostic significance. Dig Surg. 2007;24(5):331-7. doi: 10.1159/000106511. Epub 2007 Jul 27. PMID: 17664875.

16. Bezruchko NV, Rubtsov GK, Ganyayeva NB, Kozlova GA, Sadovnikova DG. Catalase of biological environments of the human body and its clinical biochemical value in endotoxicose estimation. Tomsk State Pedagogical University Bulletin. 2012;(7):949. Russian.

Received: 08.01.2021 